\title{
Extracting an Urban Growth Model's Land Cover Layer from Spatio-Temporal Cadastral Database and Simulation Application
}

\author{
Ismail Ercument Ayazli ${ }^{1 *}$, Fatmagul Kilic Gul ${ }^{2}$, Seher Baslik ${ }^{3}$, \\ Ahmet Emir Yakup ${ }^{1}$, Derya Kotay ${ }^{1}$ \\ ${ }^{1}$ Cumhuriyet University, Department of Geomatics Engineering, Sivas, Turkey \\ ${ }^{2}$ Yildiz Technical University, Department of Geomatics Engineering, Istanbul, Turkey \\ ${ }^{3}$ Mimar Sinan Fine Arts University, Department of Informatics, Istanbul, Turkey
}

Received: 3 December 2017

Accepted: 25 March 2018

\begin{abstract}
Land cover data, resolution, and time are among the important factors of SLUETH and similar urban growth simulation models (UGSM). Multitemporal satellite images are often used in many UGSM projects and settlement area, forest, agricultural area, highway, and temporal land cover classes can be extracted from satellite data using image processing techniques. However, land cover classes can also be economically obtained with higher resolutions from cadastral maps. Parcels and attributes in the geographical and temporal database may support a more realistic on-land cover change. The aim of our study is to determine the land cover change from 1961 to 2014 with temporal cadastral data and simulate urban expansion starting from 2030 to 2070 using SLUETH, a cellular automata (CA) based UGSM, for densely the populated Sancaktepe District in the metropolitan area of Istanbul. The population of Sancaktepe increased over 55\% between 1961 and 2014, while approximately half of the forest and agriculture areas were transformed to a settlement area. According to the simulation results, if necessary precautions are not taken, almost all of the remaining forest and agricultural areas will be converted into residential areas by 2070 .
\end{abstract}

Keywords: land cover change, cadastral data, urban growth, cellular automata

\section{Introduction}

The United Nations (UN) has organized various meetings since 1987 and proposed the land management and land administration models as a component of sustainable development to protect natural and

*e-mail: eayazli@cumhuriyet.edu.tr environmental resources and improve the quality of life in the world [1-2]. In this context, cadaster has new and important responsibilities and evolves to land administration defined as an implementation tool of land management policies [3]. As part of a sustainable development paradigm, urban growth is required to be kept under control according to the understanding of land management. In other words, land management requires estimating how the land cover will change [3] 
and in which direction the urbanization will be in the coming years, as well as knowing the current structures of the cities for using natural and environmental resources productively [4]. Moreover, cadaster will provide basic data for monitoring urban growth $[5,6]$.

Due to the dynamic and complex structure of cities, the system approach and complexity theory have been used in planning for modeling urban growth since the mid-20th century. Creating UGSMs can now be easily made thanks to developments in computer technology. Therefore, a number of simulation models have been generated to predict, analyze, and monitor urbanization [4, 6-14]. The well-known model among them is CA and it is frequently used to follow the changes caused by urban growth on land cover. CA, which has five basic elements including space, state, neighborhood, transition rules, and time, is an operating system that allows us to divide a state into cells and to predict the future state of each cell according to the state of neighboring cells [4].

Although several institutions have been created by CA-based simulation models in the world, the most popular one is the SLEUTH urban growth model, of which initial study was applied in San Francisco, generated by Keith Clarke from the University of California Santa Barbara Geography Department [15]. The successful findings of the study have caused the implementation of various projects utilizing SLEUTH worldwide [4, 9-10, 16-18]. As input data, at least four periods of urban areas and two periods of transportation, two-period land cover, one-period slope, excluded area, and hillshade data are required to model a simulation of urban growth while running the software in three phases [15].

The first phase is called Test while creating the simulation model. In this step, whether the data are prepared in the format desired by the software is checked for the calculations of the data to be used in the system. The data set can be used in the calibration phase if they have been produced in the essential standards of software, such as same projection, same resolution, required naming format, 8-bit grayscale images, and same map extent [15].

After testing the data set, the calibration phase is carried out in three steps, and it is aimed to calculate the most suitable growth coefficient values for the estimation phase. The best fit coefficient values are determined using the brute force calibration (BFC) method according to 13 criteria [19-20]. Although there is not yet a consensus on which of these criteria will be used to determine the coefficient, it is recommended to determine the coefficients by the optimum SLEUTH metric (OSM) method from recent studies in the literature [21].

The OSM method was developed by Dietzel and Clarke (2007), in which coefficients are determined using compare, pop, edges, clusters, slope, x-mean, and y-mean criteria, from the criteria calculated after each calibration [21]. According to the OSM method, it is passed to the prediction phase, where the UGSM will be produced for the future after calculating the coefficients, and UGSM is created for the year for which the estimation will be made.

The main data of UGSMs are multitemporal land cover layers and are generally obtained from satellite imagery [4, 22-25]. Data such as land cover, slope, transportation, plan decisions and constraints, administrative borders, lithology and structural features, and socio-economic data, etc., are generally used in CA-based studies in which urban growth is monitored. Pixel sizes vary according to the purpose of the project between $10 \mathrm{~m}$ and $500 \mathrm{~m}$ [19]. The main data of UGSM land cover were generally obtained from satellite imagery or land use/land cover (LULC) databases [4, 22-24], whereas cadastral data are frequently used in the analysis of the accuracy of land cover data generated from satellite images [25]. However, in this study, LULC were generated from land title deeds and parcels in the Turkish cadastral registration system to generate land cover classes precisely. For this reason, the study is one of the rare studies in which LULC is produced from cadastral data.

In this study, four land cover data classes including settlement area, forest areas, agricultural area, and open spaces were extracted from cadastral maps in four different periods (1961, 1992, 2001, and 2014). Other multitemporal layers such as transportation, building, administrative borders, and slope were derived by using various other data sources.

Three different simulation models for the years 2030, 2050, and 2070 were created by processing the obtained data in a database, and short, medium, and long-term changes in land cover were determined using SLUETH. According to the results, the direction of urbanization in the study area is from west to east. In particular, the open spaces, agricultural areas, and forests in the neighborhoods located in the east of the district are expected to be transformed into settlement areas from the short term and to increase gradually until 2070 .

\section{Material and Methods}

\section{Study Area}

Sancaktepe District was established in 2008. It neighbors Sultanbeyli, Cekmeköy, Kartal, Maltepe, Pendik, Atasehir, and Umraniye districts, and has 19 neighborhoods (Fig. 1). Its area is approximately $62 \mathrm{~km}^{2}$ and it is near a drinking water basin in metropolitan İstanbul. Its population increased from 229,093 to 354,882 during the seven years from its establishment until 2015, with 55\% increased ratios [26].

Significant natural and environmental areas have been under threat of urbanization due to the land cover that changed as a result of rapid urbanization experienced in the district, a large part of which has been included within Omerli Watershed Protection Zone 




Fig. 1. Administrative borders of Sancaktepe District.

by the Istanbul Water and Sewerage Administration (IWSA). Rapid population growth and migration over the past years have brought along squatting, illegal housing, and uncontrolled urbanization and led to changes in the land cover, and this situation has played an important role in the diversification of the property pattern. The geographical location, increasing population density, and transportation projects of Sancaktepe are important factors for the investigation of land cover changes.

\section{Model Background}

The cadastral maps obtained from Land Registry and Cadaster II $^{\text {nd }}$ Regional Directorate and the zoning plans from Sancaktepe Municipality need to be transferred to the urban growth database for preparation of the settlement area, building stock, land cover, and accessibility data used in the study. Therefore, the cadastral data, zoning plans and the data of the years during which zoning movements were intense in the region were first analyzed. Four different time zones appear when cadastral map production and the intensity of zoning activities are taken into account. The studies of the institution cadaster were initiated in 1956 in the project area, and a total of 33 cadastral maps were produced at different scales until 1962. 56 cadastral maps between 1988-1992 and a total of 82 cadastral maps between 1997-2002 were produced, and zoning mobility was also most intense in the region in this period. The range between 2008 and 2014 constitutes the fourth period for Sancaktepe. In the last period, more than 30 cadastral maps were produced, and the first zoning plan in which Sancaktepe was handled as a whole was made.

Accordingly, the periods of the study were determined as 1961, 1992, 2001, and 2014. Thus, important events in the name of urban growth in the

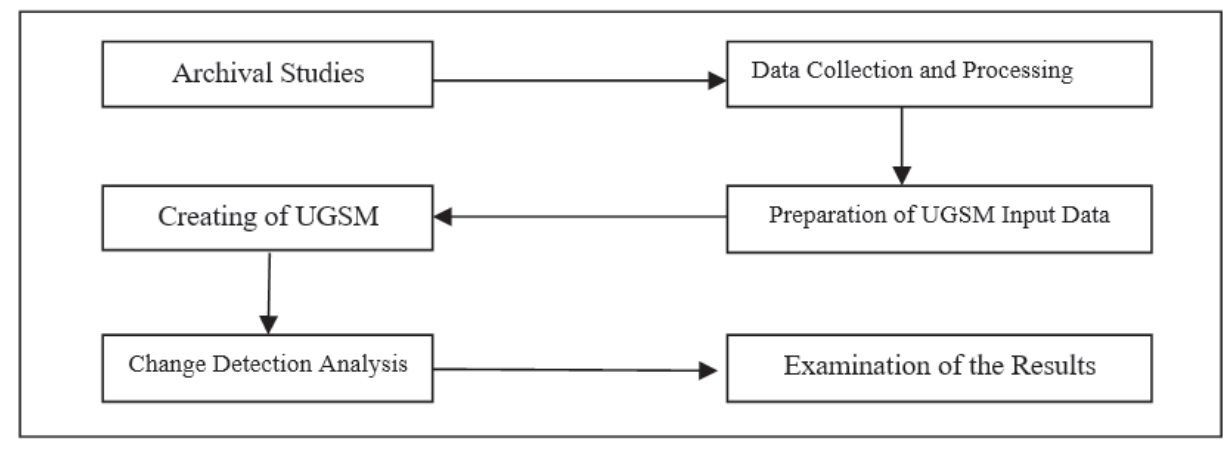

Fig. 2. Workflow of creating UGSM. 


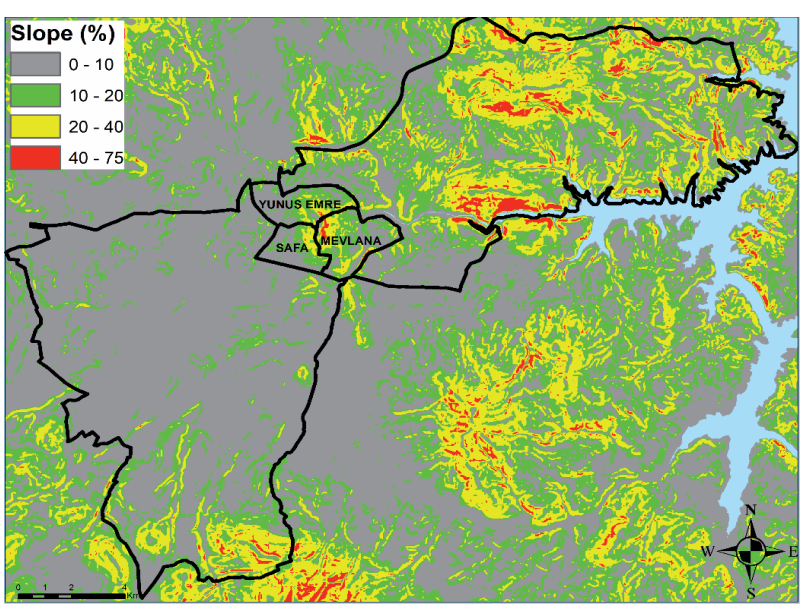

Fig. 3. Neighborhoods with a slope greater than $40 \%$

historical process were considered, and simulation models were also prepared for the future according to the current data.

The obtained data were stored in a database management system to perform the storage, organization, analysis, and presentation of the data to be used in creating the simulation model in an easy way. The Parcel class in which settlement area and land cover data would be produced, the Road class in which accessibility data would be prepared, and the Building class in which building stock data would be stored were created within the data sets.

\section{Data Processing and Creating the Simulation Model}

The procedure steps followed in the study are shown in Fig. 2 and were initiated by the archival studies carried out at Umraniye Cadaster Department. More than 70.000 parcel data from different years which were obtained after the archival study were organized in the GIS environment, and input data were prepared to create UGSM. After UGSM had been created, change detection analysis was performed, the direction and effects of urban growth were examined, and the results obtained were studied.
The first step of the study is the archival study carried out at Land Registry and Cadaster II ${ }^{\text {nd }}$ Regional Directorate to reveal the property pattern of Sancaktepe. In these studies, parcel-based settlement area, land cover data, and transportation data (data for 2006 and 2013 were obtained from IMM) were produced for 1961, 1992, 2001, and 2014. In this way, the cadastral data of the past years that are not regularly recorded in the Turkish cadastral system have been recorded in the Urban Growth Database. The second phase, data collection and processing, was initiated after having completed archival studies. The suitability, zoning, accessibility, land cover, and socioeconomic data, which are the basic data needed by the UGSM, were produced in this phase.

The group classified as suitability data have spatial information about whether the land cover function will be suitable for the settlement area in the future. The parcel-based settlement area data for 1961, 1992, 2001, and 2014 produced from cadastral maps, and the slope data produced from DEM, obtained from GCM, and having $10 \mathrm{~m}$ spatial resolution were used as suitability data in the study. Due to the Turkish Cadastral System, in the first period, gaps arose in the study area. These gaps were removed by land cover data produced by classifying the Landsat satellite image of 1972. Four land-cover classes produced from cadastral data settlement area, agricultural areas, forests, and open spaces - were included in the study.

Building data produced from cadastral maps and obtained from IMM were overlapped with parcel data, and the weight of the parcels on which there were buildings and the weight of non-parcel data were set as 100 and 75, respectively, and they were included in fourperiod settlement area data.

The slope criterion can be adjusted while establishing the simulation model, and this value is defined as $21 \%$ in software. However, it was determined that urbanization activities took place even in places with a slope of over $40 \%$ in the region. In particular, it was determined that urbanization occurred in places where the slope was greater than $40 \%$ in the region, including Mevlana, Safa, and Yunus Emre neighborhoods (Fig. 3). Therefore, the slope criterion was set as $80 \%$ in the model.

Table 1. Summary of calibration results.

\begin{tabular}{|c|c|c|c|c|c|c|c|}
\hline \multirow{3}{*}{ Coefficient Name } & \multirow{2}{*}{\multicolumn{2}{|c|}{$\begin{array}{c}\text { First Calibration } \\
\text { Number of iterations }=5\end{array}$}} & \multirow{2}{*}{\multicolumn{2}{|c|}{$\begin{array}{c}\text { Precise Calibration } \\
\text { Number of iterations }=8\end{array}$}} & \multirow{2}{*}{\multicolumn{2}{|c|}{$\frac{\text { Final Calibration }}{\text { Number of iterations }=10}$}} & \multirow{3}{*}{$\begin{array}{l}\text { Coefficient } \\
\text { Values }\end{array}$} \\
\hline & & & & & & & \\
\hline & Range & Step & Range & Step & Range & Step & \\
\hline Dispersion & $0-100$ & 25 & $50-100$ & 10 & $100-100$ & 1 & 100 \\
\hline Breed & $0-100$ & 25 & $75-100$ & 5 & $95-100$ & 1 & 100 \\
\hline Spread & $0-100$ & 25 & $50-100$ & 10 & $60-60$ & 1 & 60 \\
\hline Slope & $0-100$ & 25 & $75-100$ & 5 & $75-75$ & 1 & 75 \\
\hline Road Gravity & $0-100$ & 25 & $25-100$ & 15 & $75-100$ & 6 & 82 \\
\hline
\end{tabular}


Table 2. Land cover for 1961 and 2014.

\begin{tabular}{|c|c|c|c|c|}
\hline \multirow{2}{*}{ Land cover } & \multicolumn{2}{|c|}{1961} & \multicolumn{2}{c|}{2014} \\
\cline { 2 - 5 } & $\begin{array}{c}\text { Number of } \\
\text { Pixels }\end{array}$ & $\begin{array}{c}\text { Ratio } \\
(\%)\end{array}$ & $\begin{array}{c}\text { Number of } \\
\text { Pixels }\end{array}$ & $\begin{array}{c}\text { Ratio } \\
(\%)\end{array}$ \\
\hline Settlement Area & 2,290 & 0.1 & 201,097 & 11.4 \\
\hline Agricultural areas & 287,009 & 16.3 & 108,869 & 6.2 \\
\hline Forest Areas & 271,087 & 15.4 & 235,353 & 13.4 \\
\hline Open spaces & 15,774 & 0.9 & 12,326 & 0.7 \\
\hline
\end{tabular}

In the 1:100.000-scaled environment plan (EP) prepared for Istanbul, a very small region within the boundaries of the district carries a geological risk, and this is a region that has already completed its urbanization. Therefore, the geological structure was not taken into account in the model created.

The zoning data group includes data that are designed in plans, direct urban growth, and impose some restrictions. It includes restrictions such as areas suggested for housing, proposed agricultural areas, superstructure facilities such as bridges, suggested roads, etc., functions, and protection areas. However, as seen in Fig. 4, urbanization activities are available even in places with a slope of over $40 \%$ when the slope data included in the model is examined within the scope of the suitability data. Therefore, no zoning data that would impose a restriction to the model was used by considering the urbanization of Istanbul.

Highways, railways, and other transportation data are included in the transportation/accessibility data class. The accessibility data for the first, second, and third periods were produced by digitizing the cadastral maps of the relevant periods. However, it was determined that the roads opened were not processed in the maps because some cadastral maps were out of date in the second period, and the transportation data of the second period were produced using the satellite images and aerial photographs of the relevant period in the IMM City Guide. Transportation data for 2006 and 2013 were obtained from the IMM and the road data of the fourth and fifth periods were organized respectively. Five-period accessibility road data are weighted as 100 for motorways, 75 for main streets, 50 for streets, and 25 for village roads.

Three separate datasets with $10 \times 10 \mathrm{~m}, 20 \times 20 \mathrm{~m}$, and $40 \times 40 \mathrm{~m}$ pixel sizes were created in simulation models using CA-based SLEUTH software. In these data sets, the slope, land cover, areas out of urbanization, settlement area, transportation, and hillshade data were created according to the standards of the software [18, 20]. Three UGSMs were created for the years 2030, 2050 , and 2070 by making the necessary changes in the scenario files. The summary of the calibration results of the calculations made during the calibration phase is presented in Table 1.

\section{Results}

To find out land cover change in the short, middle, and long runs, UGSMs were generated for the years 2030, 2050, and 2070. After creating UGSM using SLEUTH, change detection analysis was made for determining the effects and direction of urbanization. According to results, the main part of forests, agricultural areas, and open spaces will be transformed into settlement areas especially located on the eastern side of the district, in a short run. After calculating best fit values of growth coefficients for land cover by OSM methods, three different UGSMs for Sancaktepe were created for the years 2030, 2050, and 2070, and the change detection analyses were performed between 1961-2014, 2014-2030, 2014-2050, and 2014-2070. According to the results in Table 2, the ratio of settlement area that was $0.1 \%$ in 1961 increased to $10.9 \%$ in 2014 .

In addition, there is a decrease of about $10.1 \%$ in agricultural areas and $2 \%$ in forests within the study area. UGSM results show that the change is expected to continue in the short, medium, and long terms (Table 3).

The simulation model created using SLEUTH software based on CA includes the land cover prediction of 2070. According to the simulation result, almost all agricultural lands and open spaces are expected to be transformed into built-up areas in Sancaktepe. When transportation projects designed in our day and the urban spread structure of Istanbul are taken into account, areas located in Sancaktepe District that are not yet built-up (such as Pasakoy and its surroundings) are thought to be under intense urbanization pressure. For instance, urbanization far beyond the estimations was experienced in a short span of time of 10 years in Yenidogan region between 1990 and 2000, and a single parcel of 441 ha was urbanized by being divided into over 6.450 parcels. This rapid urbanization in Yenidogan

Table 3. Land covers expected to be transformed into settlement area in the future.

\begin{tabular}{|c|c|c|c|c|}
\hline \multirow{2}{*}{ Transformation into settlement areas } & \multicolumn{4}{|c|}{ Proportional change } \\
\cline { 2 - 5 } & $1961-2014(\%)$ & $2014-2030(\%)$ & $2014-2050(\%)$ & $2014-2070(\%)$ \\
\hline From agricultural areas & 47.5 & 23.4 & 69.9 & 83.0 \\
\hline From forests & 12.3 & 11.0 & 69.7 & 88.2 \\
\hline From open spaces & 53.8 & 24.7 & 78.2 & 90.0 \\
\hline
\end{tabular}




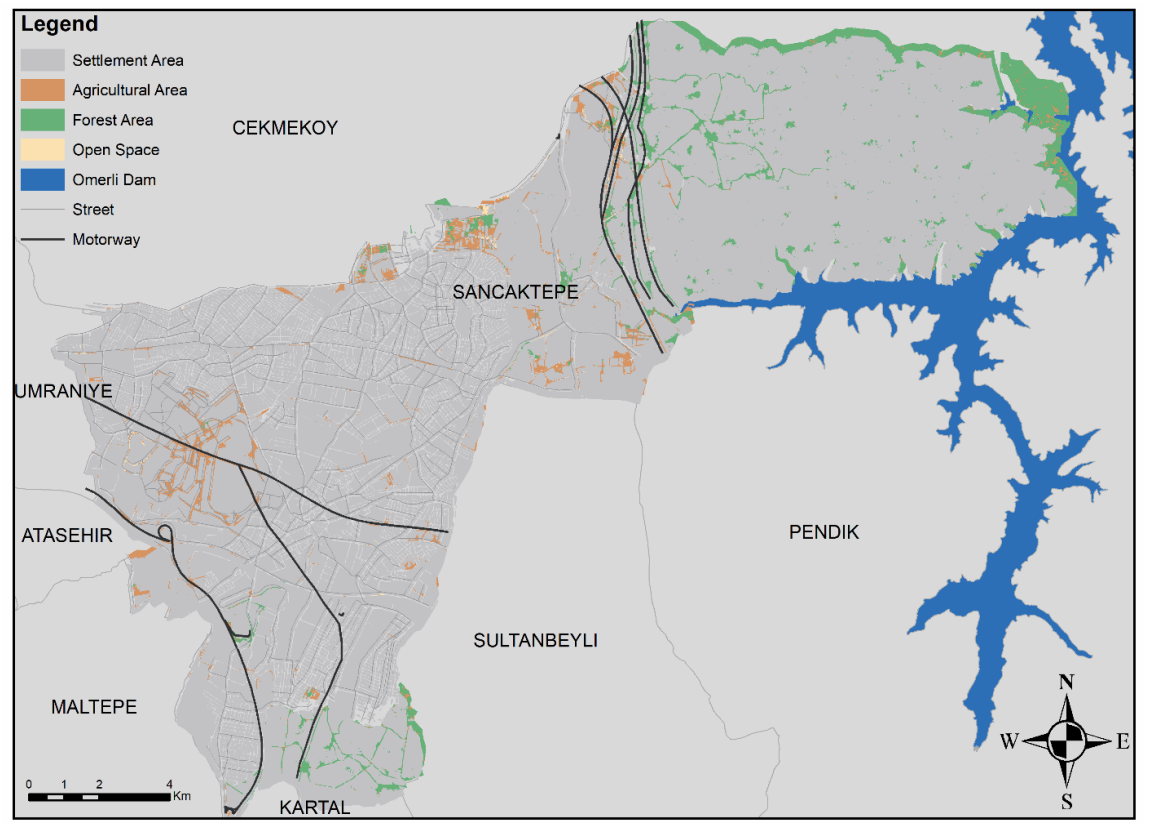

Fig. 4. Land cover of Sancaktepe for 2070.

was not seen in Pasakoy region, and its proximity to the watershed and forest areas has ensured the protection of this area and has maintained its rural character until today. Therefore, Pasakoy and the surrounding lands are one of the most important areas in the district because of its unique structure mentioned. The fact that the $3^{\text {rd }}$ Bridge's road routes pass through there gives rise to the thought that a rapid urbanization process can be initiated as in Yenidogan. The land cover predictions were produced for the years 2050 and 2070 and it is envisaged that there will be intensive construction in this region (Fig. 4).

\section{Conclusions}

The simulation models exhibit an estimate consistent with development trends, and urban housing appears above the expectations for 2070. It is understood from this simulation that the $3^{\text {rd }}$ Bridge's road routes passing through Sancaktepe District will directly affect urban development if necessary precautions are not taken.

According to the growth coefficients that were calculated as a result of calibration, the growth characteristic in Sancaktepe District breeds in different places and continues by spreading. It is interpreted that the topographic structure of the district has scarcely any effect on urbanization due to the low slope coefficient. Besides, the fact that urbanization is seen even in places where the slope is greater than $40 \%$ in Safa, Mevlana, and Yunus Emre neighborhoods (Fig. 4) supports the interpretation made.

It is expected that $83.0 \%$ of the agricultural areas and $88.2 \%$ of the forests will be transformed into the settlement areas within a period of more than 100 years.
In interviews with local people during field studies in 2015, it was verbally reported to us that the forested lands around Omerli Dam attracted the attention of political powers and investment groups.

The land cover data were produced from cadastral data within the scope of the project. Thus, the reliability of the produced data has been ensured by the state. In addition, the institution of cadaster was initiated in the 1920s in Turkey. Thus, it is possible to analyze land cover changes starting from earlier ones. However, the Turkish Republic General Directorate of Land Registry and Cadastre (GDLRC) has an important responsibility concerning the issue for data reliability and the accuracy of historical data to meet today's requirements. If GDLRC takes on responsibility for this issue, produces land cover from cadastral data, and prepares projects to initiate historical cadastral studies that are defined as four-dimensional cadaster, it will create a new resource for its own revolving funds and also will reduce the external dependency of the relevant institutions, organizations, and researchers in studies to be carried out on the subject. The UGSM produced within the scope of the project was produced within this scope, and promising results were obtained.

\section{Acknowledgements}

This study was supported by TUBITAK project No. $112 \mathrm{~K} 469$.

\section{Conflict of Interest}

The author declares no conflict of interest. 


\section{References}

1. AYAZLI I. E., HELVACI C., BATUK F., STOTER J. Designing three dimensional property right database. African Journal of Business Management, 5 (22), 9440, 2011.

2. BURDETT M. Cadastre 2034; Powering Land \& Real Property. Available online: http://www.icsm.gov.au/ cadastral/Cadastre2034.pdf (accessed on 01 Dec. 2017).

3. ENEMARK S. Land Administration Systems-managing rights, restrictions and responsibilities in land. Map World Forum. Hyderabad, India. 2009.

4. AYAZLI I.E., KILIC F., LAUF S., DEMIR H., KLEINSCHMIT B. Simulating urban growth driven by transportation networks: A case study of the Istanbul third bridge. Land Use Policy, 49, 332, 2015.

5. LIU Y., HU Y., LONG S., LIU L., LIU X. Analysis of the Effectiveness of Urban Land-Use-Change Models Based on the Measurement of Spatio-Temporal, Dynamic Urban Growth: A Cellular Automata Case Study. Sustainability, 9 (5), 1, 2017.

6. CHEN Y., LIU X., LI X. Calibrating a Land Parcel Cellular Automaton (LP-CA) for urban growth simulation based on ensemble learning. Int. J. Geog. Inf. Sci., 31 (12), 1, 2017.

7. HOSSEINALI F., ALESHEIKH A. A., NOURIAN F. Rapid Urban Growth in the Qazvin Region and Its Environmental Hazards: Implementing an Agent-Based Model. Pol. J. Environ. Stud., 23 (3), 727, 2014.

8. DEBNATH R., AMIN A.N. A geographic information system-based logical urban growth model for predicting spatial growth of an urban area. Environment and Planning B: Planning and Design, 1, 2018.

9. ASSEFA T., ALTUNKAYNAK A. Modeling Urbanization of Istanbul under Different Scenarios Using SLEUTH Urban Growth Model. Journal of Urban Planning and Development, 143 (2), 2017.

10. AYAZLI I.E., KILIC F., LAUF S., KLEINSCHMIT B., DEMIR H. Creating Urban Growth Simulation Models Driven by the Bosphorus Bridges. Fresenius Environmental Bulletin, 26 (1), 113, 2017.

11. BIHAMTA N., SOFFIANIAN A., FAKHERAN S., GHOLAMALIFARD M. Using the SLEUTH Urban Growth Model to Simulate Future Urban Expansion of the Isfahan Metropolitan Area, Iran. J Indian Soc Remote Sens, 43 (2), 407, 2015.

12. GUAN C., ROWE P. G. Should big cities grow? Scenariobased cellular automata urban growth modeling and policy applications2016. Journal of Urban Management, 5, 65, 2016.

13. JANTZ C. A., GOETZ S. J., DONATO D., CLAGGETT $\mathrm{P}$. Designing and implementing a regional urban modeling system using the SLEUTH cellular urban model. Computers, Environment and Urban Systems, 34, 1, 2010.
14. HEINSCH L., LAUF S., KLEINSCHMIT B. Modeling urban growth and land usechange with a cellular automaton in the Berlin metropolitan region. GIS-Zeitschrift für Geoinformatik, 25 (2), 56, 2012.

15. PROJECT GIGALOPOLIS. Available online: http://www. ncgia.ucsb.edu/projects/gig/index.html. (accessed on 01 Dec. 2017).

16. AKIN A., CLARKE K. C., BERBEROGLU S. The impact of historical exclusion on the calibration of the SLEUTH urban growth model. International Journal of Applied Earth Observation and Geoinformation, 27 (Part B), 156, 2014.

17. Berberoglu S., AKIN A., CLARKE K. C. Cellular automata modeling approaches to forecast urban growth for Adana, Turkey: A comparative approach. Landscape and Urban Planning, 153, 11, 2016.

18. PARK S., CLARKE K. C., CHOI C., KIM J. Simulating Land Use Change in the Seoul Metropolitan Area after Greenbelt Elimination Using the SLEUTH Model. Journal of Sensors, 2017, 1, 2017.

19. AYAZLI I. E. Simulation Model of Urban Sprawl Driven by Transportation Networks: $3^{\text {rd }}$ Bosphorus Bridge Example. Yildiz Technical University, Istanbul, 2011.

20. CLARKE K.C., HOPPEN S., GAYDOS L. A selfmodifying cellular automaton model of historical urbanization in the San Francisco Bay Area. Environment and Planning B: Planning and Design, 24, 247, 1997.

21. DIETZEL C., CLARKE K. C. Toward Optimal Calibration of the SLEUTH Land Use Change Model. Transactions in GIS, 11 (1), 29, 2007.

22. DU Y., TEILLET P.M., CIHLAR J. Radiometric normalization of multitemporal high-resolution satellite images with quality control for land cover change detection. Remote Sensing of Environment, 82 (1), 123, 2002.

23. JIN S., YANG L., ZHU Z., HOMER C. A land cover change detection and classification protocol for updating Alaska NLCD 2001 to 2011. Remote Sensing of Environment, 195, 44, 2017.

24. KIRUKI H M., VAN DER ZANDEN E.H., MALEK Ž., VERBURG P.H. Land Cover Change and Woodland Degradation in a Charcoal Producing Semi-Arid Area in Kenya. Land Degrad. Develop., 28, 472, 2017.

25. NOURQOLIPOUR R., BALASUNDRAM S.K., AHMAD N.B., SOOD A.M., BUYONG T. Predicting the Effects of Urban Development on Land Transition and Spatial Patterns of Land Use in Western Peninsular Malaysia. Appl. Spatial Analysis, 9 (1), 1, 2014.

26. Turkish Statistical Institute Web Page. Available online: https://biruni.tuik.gov.tr/medas $/ ? \mathrm{kn}=95 \&$ locale $=$ tr. (accessed on 01 Dec. 2017). 